\title{
Impact of Junk food on Physical and Mental health of the Youngsters in Bhopal city - A Cross Sectional Survey Study
}

\author{
Research Article
}

\section{Ravi Verma1, Charu Bansal2*, Trupti Jain ${ }^{3}$}

1. Medical Officer, Govt. Ayurvedic Dispensary, Sheopur, MP. India

2. Professor, 3. Lecturer, Post Graduate Department of Swasthavritta, Pt. KLS Govt. Ayurveda College \& Institute, Bhopal M.P. India

\begin{abstract}
Background- Ayurveda has given a unique concept of Viruddha Ahara. Junk food an energy-dense food could be consider as Viruddha Ahara because of its serious physical and mental health consequences. Aim - Find out the frequency of consumption of Junk food preparation and their effects on Physical \& Mental health in the youngsters of Bhopal city with special reference to Viruddha Ahara. Study Design- was Observational cross sectional study. Material and Method- Modified Questionnaire based on WHO STEPS1, 2 and 3 guidelines was used to collect the data. 600 youngsters of age group between 12-25 years from various schools and colleges of Bhopal city were selected by stratified random sampling technique and Statistical Analysis was done with epi info ${ }^{\mathrm{TM}}$ version 7 software. Appropriate statistical tests were applied such as frequency distribution, cross tabulation (M x N/ $2 \times 2$ Table), chi square test, z statistics and logistic regression analysis. Odds ratios (OR) with $95 \%$ confidence intervals (C.I) and p-value (significant $<0.05$ ) were also calculated as per need. Result- It was observed that all subjects were consuming different kinds of junk food with high mean frequency that was 3.28 days per week. Maximum youngsters were suffering from various physical and mental health consequences like $80.83 \%$ subjects were suffering from nutritional problem, $73.50 \%$ skin problems, $73.33 \%$ GIT problems and $58.67 \%$ had anxiety disorder and $38.50 \%$ had recognised with mood disorder. Conclusion: The result of the survey study indicating that serious health consequences are developing in youngsters by consumption of viruddha ahara (Junk Food) and that could be converted them in chronic disease patients in near future.
\end{abstract}

Key Words: Viruddha Ahara, Junk Food, Junk Food impact on health, Impact of Viruddha Ahara on Health.

\section{Introduction}

Food is very much essential for the sustainment of life of all living beings. The consumption of Viruddh Ahara is considered important causative factor for several acute to chronic diseases and even death in Ayurveda (1). Various research studies reported junkfood can trigger overweight, and other health problems among adolescents. Increasing trends of Obesity in youngsters due to consumption of Junk food has been also responsible for risk factors for type-2 diabetes and Cardiovascular diseases (2). By virtue of its health effects and preparation Junk food could be consider as Viruddha Ahara.

\section{Aim \& Objectives of the Study}

Find out the most commonly consumed Junk food preparations, their frequency along with their Physical \& Mental health consequences on the youngsters of Bhopal city, M.P. with special reference to Viruddha Ahara.

\section{* Corresponding Author:}

\section{Charu Bansal}

Professor, P.G. Department of Swasthavritta,

Pt. KLS Govt. Ayurveda College \& Institution,

Bhopal. Madhya Pradesh. India.

Email Id: bansalcharu73@rediffmail.com

\section{Methodology}

Study Design

This study was an observational cross sectional study.

\section{Duration of Study}

8 months (1 ${ }^{\text {st }}$ August 2017 to $31^{\text {st }}$ March 2018)

Place of Study

Bhopal City.

\section{Ethical clearance}

The study protocol was approved by the Institutional Ethical Committee dated on 28/05/16.

\section{Pilot Study}

Before main study the pilot study was carried out to assess the feasibility and applicability of the questionnaire in 50 subjects.

Sample Design: Sampling was done by using disproportionate stratified random sampling technique (DSRS). The study population divided into 2 strata on the bases of age then irrespective of cast, creed, religion, sex etc. subjects between the age group of 12 to 25 years and those willingly sign the informed written consent were selected from OPD \& IPD of Department of Swasthavritta, Panchkarma, 
Kayachikitsa of Pt. Khushilal Sharma Govt. Autonomous Ayurveda College \& Institute and from schools and other colleges of Bhopal City.

\section{Sample Size: was 600}

For the calculation of the required sample size, the formula used was- $\left[\mathrm{N}=\mathrm{z}^{2} \mathrm{P}(1-\mathrm{P}) / \mathrm{e}^{2}\right]$ where $\mathrm{N}=$ sample size, $\mathrm{z}=$ statistics for $\alpha$ error, $\mathrm{P}=$ estimated prevalence of junk food consumption, $\mathrm{e}=$ precision error (marginal error). According to prevalence of junk food consumption rate of previous studies (10-50\%) (3) and at $5 \%$ allowable error the calculated sample size was 384 but on the convenience bases sample size was increased to 600 to increase the confidence level.

\section{Inclusion Criteria}

All youngsters between the age group of 12 to 25 years and willing to participate in study and ready to give consent were included in the study.

\section{Data Collection Instrument}

Modified Questionnaire based on World Health Organization

(WHO) Steps wise approach for Chronic Disease Risk Factor Surveillance i.e. WHO

STEPS1 and STEPS 2, STEPS 3 guidelines, Patient Health Questionnaire (PHQ-9), questionnaire for Attention deficit hyperactivity disorder (ADHD), Generalized anxiety and Mood disorder and Anger assessment. This questionnaire also contained questions which could be assess the physical activity, dietary pattern, junk food consumption pattern, viruddha ahara consumption pattern, sleeping pattern, physical and mental health problems of the study subjects.

Investigation: Height, weight, Body Mass Index (BMI), waist-hip ratio, abdominal Girth, Systolic and Diastolic blood pressure were carried out in all subjects. Random blood sugar and triglycerides and High-density lipoprotein (HDL) cholesterol and Haemoglobin test were carried out in some selected patients.

\section{Survey Methodology}

Structured interview schedule was employed using pre structured modified questionnaire and were recorded Demographic details, current health status (biochemical measurements), health related risk factors such as physical activity, dietary pattern, junk food consumption pattern, viruddha ahara consumption pattern, sleeping pattern, physical and mental health problems of the study subjects. Each day average 5 participants were invited for interview and anthropometric measurements and simple clinical examinations were conducted.

Variables were recorded as, Blood pressure (in sitting posture, with mercurial sphygmomanometer), height in $\mathrm{cm}$, weight in $\mathrm{Kg}$, Abdominal girth in $\mathrm{cm}$, waist and hip circumference in $\mathrm{cm}$. Selected
Participants were provided the appointment date and time (usually the next morning) for laboratory investigations - haemoglobin, random blood sugar, and triglyceride and HDL level.

Socioeconomic status of the Subjects was classified as per the modified Kuppuswamy scale. Raised Waist Circumference: $>90 \mathrm{~cm}$ for males and $>$ $80 \mathrm{~cm}$ for females in age between 19-25 years. WC $>95^{\text {th }}$ percentile was considered Raised WC in age between 12-18 years (4). Overweight and obesity defined by BMI for gender and age. BMI $>85^{\text {th }}$ percentile of reference data was considered overweight, and those with a BMI $>95^{\text {th }}$ percentile was considered obese (5). Abdominal Obesity (Waist hip ratio): $\geq 0.85$ for female and $\geq 0.90$ for male in age between 19-25 years. As per guideline of world health organization WHR $>95^{\text {th }}$ percentile was considered Raised WHR in age between 12-18 years. Raised Abdominal Girth: $>90$ for females and $>100$ for male in age between 19-25 years. $>95^{\text {th }}$ percentile was considered Raised AG in age between 12-18 years. Hypertension: Defined as systolic blood pressure (SBP) $\geq 140 \mathrm{mmHg}$ or diastlolic blood pressure (DBP) $\geq 90$ $\mathrm{mmHg}$ in age between 19-25 years. $>95^{\text {th }}$ percentile was considered Raised HTN in age between 12-18 years. As per guideline of WHO Anemia defined as $\mathrm{Hb}$ Male- $<13 \mathrm{gm} \%$, in Female $<12 \mathrm{gm} \%$. The severity of anemia was graded as mild ( $\mathrm{Hb} 10-12$ gm \%), moderate (Hb. 7-10 gm \%) and severe (Hb. $<7 \mathrm{gm} \mathrm{\% ).}$ Physically inactivity considered not involved in at least 30 minutes of regular moderate to vigorous activity at least 5 days in a week. Questions were asked to subjects regarding dietary habit, junk food consumption pattern which they were following since last 1 year. Duration of junk food consumption was categorized as 1-3 years, $>$ 3 years and $>6$ years. Meal timing was categorized as regular and irregular. Lunch time was categorized as before $1 \mathrm{pm}$ and after $1 \mathrm{pm}$ and Dinner time before 8 $\mathrm{pm}$ and after $8 \mathrm{pm}$. Number of servings and frequency of Junk food consumption per week was asked in order to assess the junk food pattern of the subject. Question regarding viruddha ahara consumption were asked in Yes or No.

\section{Data Management and Analysis}

The data thus collected manually was transformed to Microsoft Excel and analysis was done on epi info ${ }^{\mathrm{TM}}$ version 7. (Means, $95 \%$ confident interval (CI), standard deviation (SD) and /or standard error (SE) were included in descriptive analysis) appropriate statistical tests were applied such as frequency distribution, cross tabulation ( $\mathrm{M} \times \mathrm{N} / 2 \times 2$ Table), chi square test, $\mathrm{z}$ statistics and logistic regression analysis and result was presented in the form of tables and graphs. Odds ratios (OR) with 95\% confidence intervals 
(C.I) and p-value (significant $<0.05$ ) were calculated as per need.

\section{Observations and Results}

In the present study out of total 600 subjects $37 \%(n=222)$ were male and $63 \%(n=378)$ were female. Subjects between $12-18$ years were $54 \%(\mathrm{n}=324)$, among them $48 \%(\mathrm{n}=156)$ and $52 \%(\mathrm{n}=168)$ were and female respectively. Subjects between $19-25$ years were $46 \%(n=276)$, among them $24 \%(n=66)$ and $76 \%(n=210)$ were male and female respectively.

\begin{tabular}{|c|c|}
\hline Max 52.17\% & Youngsters were Graduate \\
\hline Max $79.50 \%$ & belonged to middle class socioeconomic status \\
\hline $94.17 \%$ & belonged to Hindu community \\
\hline $48 \%$ and $67 \%$ & Vata-Pittaj and Vata-Kaphaj Prakriti respectively \\
\hline $55.17 \%$ & Having Madhyama satwa \\
\hline $12.50 \%(n=75)(M-39, F-36)$ & Were found overweight \\
\hline $28.33 \%(n=170, M-72, F-98)$ & Subjects were having raised WHR \\
\hline $6.17 \%$ & Having raised Abdominal Girth. \\
\hline $\begin{array}{l}\text { Out of } 176 \text { subjects }(69.88 \%) \\
\text { subjects (M-12, F-111) }\end{array}$ & $\begin{array}{l}\text { Were found anaemic, in which } 88 \text { were mild anaemic (M-11, F-77), } 34 \text { were } \\
\text { moderate anaemic (M-1, F-33) and only } 1 \text { female subject was found severe } \\
\text { anaemic. }\end{array}$ \\
\hline
\end{tabular}

\section{Lifestyle Observation}

$58 \%$ subjects were vegetarian. $26 \%$ subjects were consuming junk food for $1-3$ years, $32 \%$ subjects for $3-6$ Years and $42 \%$ since more than 6 Years. Mean frequency of junk food consumption was 3.28 days per week. $11 \%$ subjects were consuming junk food throughout the day and 10\% subjects at late night (after $10 \mathrm{pm}$ ) and 79\% subjects were at any time. Maximum $62 \%$ subjects prefer to take outside meal at evening time, $20 \%$ at lunch time, $12.17 \%$ at dinner time and only $5.67 \%$ were during breakfast. $68.87 \%$ were irregularly and $31.33 \%$ taking their meal regularly. $71 \%$ subjects were taking their lunch after $1 \mathrm{pm} .83 \%$ subjects were taking their dinner after $8 \mathrm{pm} .36 .17 \%$ were having disturbed sleep.70\% taking 6-8 hours sleep at night, $15 \%$ were taking more than 8 hours sleep and $15 \%$ were taking sleep less than 6 hours at night. 91\% were slept after $10 \mathrm{pm}$ in which most of them were slept after $12 \mathrm{pm} .51 \%$ subjects were found habitual for day dreaming. Frequency of various kinds of Junk food and Viruddha Ahara by survey participants had been recorded and represented in the table No 2 and 3.

\begin{tabular}{|c|c|c|c|c|c|}
\hline $\begin{array}{l}\text { Type of Junk } \\
\text { Food }\end{array}$ & $\begin{array}{c}\text { 12-18 Years } \\
(\mathrm{n}=324)\end{array}$ & $\begin{array}{c}\text { 19-25 Years } \\
(\mathrm{n}=276)\end{array}$ & $\begin{array}{c}\text { Total } \\
(\mathbf{n}=\mathbf{6 0 0})\end{array}$ & $\begin{array}{c}\text { Male } \\
(\mathbf{n}=\mathbf{2 2 2})\end{array}$ & $\begin{array}{c}\text { Female } \\
(n=378)\end{array}$ \\
\hline Salty Snacks & $\begin{array}{c}249 \\
(54.01 \%)\end{array}$ & $\begin{array}{c}212 \\
(45.99 \%)\end{array}$ & $\begin{array}{c}461 \\
(76.83 \%)\end{array}$ & $\begin{array}{c}178 \\
(38.61 \%)\end{array}$ & $\begin{array}{c}283 \\
(61.39 \%)\end{array}$ \\
\hline Sweet Junk Food & $\begin{array}{c}237 \\
(53.62 \%)\end{array}$ & $\begin{array}{c}205 \\
(46.38 \%)\end{array}$ & $\begin{array}{c}442 \\
(73.67 \%)\end{array}$ & $\begin{array}{c}176 \\
(39.82 \%)\end{array}$ & $\begin{array}{c}266 \\
(60.18 \%)\end{array}$ \\
\hline $\begin{array}{l}\text { Bakery Based } \\
\text { Junk Food }\end{array}$ & $\begin{array}{c}171 \\
(51.38 \%)\end{array}$ & $\begin{array}{c}162 \\
(48.65 \%)\end{array}$ & $\begin{array}{c}333 \\
(55.50 \%)\end{array}$ & $\begin{array}{c}128 \\
(38.44 \%)\end{array}$ & $\begin{array}{c}205 \\
(61.56 \%)\end{array}$ \\
\hline $\begin{array}{l}\text { Chinese Junk } \\
\text { Food }\end{array}$ & $\begin{array}{c}177 \\
(56.19 \%)\end{array}$ & $\begin{array}{c}138 \\
(43.81 \%)\end{array}$ & $\begin{array}{c}315 \\
(52.50 \%)\end{array}$ & $\begin{array}{c}130 \\
(41.27 \%)\end{array}$ & $\begin{array}{c}185 \\
(58.73 \%)\end{array}$ \\
\hline $\begin{array}{l}\text { Indian Junk } \\
\text { Food }\end{array}$ & $\begin{array}{c}253 \\
(53.38 \%)\end{array}$ & $\begin{array}{c}221 \\
(46.62 \%)\end{array}$ & $\begin{array}{c}474 \\
(79.00 \%)\end{array}$ & $\begin{array}{c}183 \\
(38.61 \%)\end{array}$ & $\begin{array}{c}291 \\
(61.39 \%)\end{array}$ \\
\hline $\begin{array}{l}\text { Other type of } \\
\text { Junk Food }\end{array}$ & $\begin{array}{c}117 \\
(60.00 \%)\end{array}$ & $\begin{array}{c}78 \\
(40.00 \%)\end{array}$ & $\begin{array}{c}195 \\
(32.50 \%)\end{array}$ & $\begin{array}{c}86 \\
(44.10 \%)\end{array}$ & $\begin{array}{c}109 \\
(55.90 \%)\end{array}$ \\
\hline $\begin{array}{l}\text { Sweetened } \\
\text { Beverages }\end{array}$ & $\begin{array}{c}147 \\
(53.07 \%)\end{array}$ & $\begin{array}{c}130 \\
(46.93 \%)\end{array}$ & $\begin{array}{c}277 \\
(46.17 \%)\end{array}$ & $\begin{array}{c}120 \\
(43.32 \%)\end{array}$ & $\begin{array}{c}157 \\
(56.68 \%)\end{array}$ \\
\hline
\end{tabular}

Table No 3: Types of Viruddha Ahara Consumption Frequency by survey subject

\begin{tabular}{|l|c|c|c|c|c|}
\hline $\begin{array}{l}\text { Type of } \\
\text { Viruddha }\end{array}$ & $\begin{array}{c}\mathbf{1 2 - 1 8 y e a r s} \\
(\mathbf{n = 3 2 4 )}\end{array}$ & $\begin{array}{c}\mathbf{1 9 - 2 5} \text { years } \\
(\mathbf{n = 2 7 6})\end{array}$ & $\begin{array}{c}\text { Total } \\
(\mathbf{n = 6 0 0})\end{array}$ & $\begin{array}{c}\text { Male } \\
(\mathbf{n = 2 2 2})\end{array}$ & $\begin{array}{c}\text { Female } \\
(\mathbf{n = 3 7 8})\end{array}$ \\
\hline $\begin{array}{l}\text { Samyoga } \\
\text { viruddha }\end{array}$ & 202 & 146 & 348 & 148 & 200 \\
\hline Veerya viruddha & $(58.05 \%)$ & $(41.95 \%)$ & $(58.00 \%)$ & $(42.53 \%)$ & $(57.47 \%)$ \\
& 73 & 43 & 116 & 43 & 73 \\
& $(62.93 \%)$ & $(37.07 \%)$ & $(19.33 \%)$ & $(37.07 \%)$ & $(62.93 \%)$ \\
\hline Kala viruddha & 71 & 60 & 131 & 39 & 92 \\
& $(54.20 \%)$ & $(45.80 \%)$ & $(21.83 \%)$ & $(29.77 \%)$ & $(70.23 \%)$ \\
\hline Karma viruddha & 62 & 54 & 116 & 37 & 79 \\
& $(53.45 \%)$ & $(46.55 \%)$ & $(19.33 \%)$ & $(31.90 \%)$ & $(68.10 \%)$ \\
\hline
\end{tabular}




\begin{tabular}{|l|c|c|c|c|c|}
\hline \multicolumn{5}{|c|}{ Ravi Verma et.al., Impact of Junk Food on Physical and Mental Health of the Youngsters - A Survey Study } \\
\hline Parihar & 172 & 115 & 287 & 128 & 159 \\
viruddha & $(59.93 \%)$ & $(40.07 \%)$ & $(47.83 \%)$ & $(44.60 \%)$ & $(55.40 \%)$ \\
\hline Paka viruddha & 65 & 55 & 120 & 48 & 72 \\
& $(54.12 \%)$ & $(45.83 \%)$ & $(20.00 \%)$ & $(40.00 \%)$ & $(60.00 \%)$ \\
\hline Krama viruddha & 279 & 201 & 480 & 185 & 295 \\
& $(58.13 \%)$ & $(41.88 \%)$ & $(80.00 \%)$ & $(38.54 \%)$ & $(61.46 \%)$ \\
\hline Vidhi viruddha & 304 & 221 & 525 & 201 & 324 \\
\hline Avastha & $(57.90 \%)$ & $(42.10 \%)$ & $(87.50 \%)$ & $(38.29 \%)$ & $(61.71 \%)$ \\
viruddha & 135 & 110 & 245 & 96 & 149 \\
\hline Ajeerne Ashniyat & $(55.10 \%)$ & $(44.90 \%)$ & $(40.83 \%)$ & $(39.18 \%)$ & $(60.82 \%)$ \\
\hline Curd With Non & 102 & 105 & 207 & 92 & 115 \\
vegetarian & $(49.28 \%)$ & $(50.72 \%)$ & $(34.50 \%)$ & $(44.44 \%)$ & $(55.56 \%)$ \\
\hline Packed food & 24 & 25 & 49 & 14 & 35 \\
& $(48.98 \%)$ & $(51.02 \%)$ & $(8.17 \%)$ & $(28.57 \%)$ & $(71.43 \%)$ \\
\hline
\end{tabular}

\section{Discussion}

Today, Food habits of society are changing dramatically because of urbanization and easy availability of market food i. e. junk and fast food. The most of the market foods are having added additives and prepared with various combinations of food items those are incompatible to each other. The trends to eat market food also gradually increasing thus we are frequently exposed to various incompatible food i. e. Viruddha Ahara which causing various serious health hazards.

In present study maximum $79.5 \%$ were belonged to middle class and maximum junk food consumption as well as physical and mental health problems was also reported in this group youngsters. $48.33 \%$ subjects were belonging to Vata-Pittaj, $34.17 \%$ Vata- Kaphaj and $17.50 \%$ were Pitta Kaphaj Prakriti.

Total $55.17 \%$ subjects (M-66.77\%, F-33.23\%) were physically inactive. In age group 12-18 years $53.78 \%$ and in age group $19-25$ years $46.22 \%$ subjects were physically inactive. Ranasinghe et al. revealed the overall prevalence of inactivity in India was $18.5 \%-88.4 \%$ (6).

In the present study as per WHO criteria; $12.50 \%(\mathrm{n}=75)(\mathrm{M}-39, \mathrm{~F}-36)$ of study subjects were overweight while $2 \%(n=12 ; M-4, F-8)$ were found obese. A cross-sectional study was conducted in randomly selected 2158 school children of age 7 to 14 years of government and private schools in Indore (M.P.) has been reported $14.97 \%$ overall prevalence of obesity (7)

In the present study, out of 600 subjects $9.50 \%$ $(\mathrm{n}=57, \mathrm{M}-11, \mathrm{~F}-46)$ were having raised waist circumference; in which maximum $14.99 \%(n=40)$ from $19-25$ age group while $5.25 \%(n=17)$ have raised $\mathrm{WC}$ in 12-18 year age group. A.L. Faris, $N$ et. al. (2015) in a study suggested that Adolescent girls were mostly consuming Burgers and carbonated soft drinks and those were consuming large portion sizes of fast food had significantly higher mean waist circumference and hip circumference (8).

In total 176 subjects; $123(69.88 \%)$ subjects were found anaemic; in which maximum were females $111(90.24 \%)$. In 111 amaemic females 77 were found mild, 33 Moderate, and only 01 was found severe anaemic. According to World Health Organization the global prevalence of anemia is $24.8 \%$ (9).

In the present study Max. $46 \%$ subjects were consuming junk food since more than 6 years, $32 \%$ from more than 3 to 6 Years and 26\% from 1 to 3 years. Rouhani et al. reported that the rate of fast-food consumption has increased in the past years, particularly among children and adolescents (10).

In present study total $66 \%$ subjects $(55.81 \%$ between 12-18year age group and $44.19 \%$ in $19-25$ year age group) were taking junk food more than 3 days in week, mean frequency of junk food consumption were found 3.28 days per week. In a cross-sectional survey, Al Faris et. al., in study trends of fast food consumption among adolescent and young adult Saudi reported that $25.2 \%$ of adolescent girls and $20.3 \%$ of young adult girls consumed fast food twice or more per week (11).

In the present study it was observed that subjects those were consuming junk food 3 to 4 day per week were overweight i.e.19.32\% $(n=32)$. In another study, $\mathrm{Li} \mathrm{M}$ et al., and Savige et. al., found that, adolescents aged 11-17 years those were overweight or obese were significantly frequent users of fast foods (once or more in a day) $(12,13)$.

In this study $6.33 \%$ subjects were almost every day consuming fast food. In a longitudinal American study, Healthy girls $(n=101)$ between the ages of 8 and 12 years at baseline and 11 and 19 years at the Massachusetts Institute of Technology, showed that increasing frequency of eating quick-service food was associated with increasing z-BMI in female adolescents (14).

In the present study observed that the $62.17 \%$ youngsters were consuming Junk food mainly in the form of snacks from shops during evening after the end of school/college/work.

$76.83 \%$ subjects were consuming salty snacks and they were associated with skin problems $(\mathrm{OR}=1.38$, $95 \%$ CI $0.89 ; 2.13)$, Respiratory problems $(\mathrm{OR}=1.70$, $95 \%$ CI $0.89 ; 3.24)$, Anorectal problems $(\mathrm{OR}=1.48$, $95 \%$ CI $0.73 ; 2.99)$ and Indriye Daurbalya $(\mathrm{OR}=1.59$, $95 \%$ CI $0.93 ; 2.72)$.

$73.67 \%$ subjects were consuming sweet junk food. They were associated with GIT problems $(\mathrm{OR}=1.31,95 \%$ CI $0.85 ; 2.02)$, Anorectal problems 
$(\mathrm{OR}=1.51,95 \%$ CI $0.78 ; 2.94)$, Hypothyroidisms $(\mathrm{OR}=1.33,95 \%$ CI $0.35 ; 5.02)$, Indriye Daurbalya $(\mathrm{OR}=1.34,95 \%$ CI $0.81 ; 2.23)$ and with Anger $(\mathrm{OR}=1.79,95 \%$ CI $1.15 ; 2.77)$.

$55.50 \%$ subjects were consuming Bakery based junk food. They were associated with Anorectal problems $(\mathrm{OR}=1.58,95 \% \mathrm{CI} 0.90 ; 2.76)$, Menstrual problems $(\mathrm{OR}=1.22,95 \% \mathrm{CI} 0.84 ; 1.77)$, Hypothyroidism $(\mathrm{OR}=1.97,95 \% \mathrm{CI} 0.58 ; 6.65)$ and Kidney Stone $(\mathrm{OR}=2.00,95 \% \mathrm{CI} 0.68 ; 5.87)$.

$52.50 \%$ subjects were consuming Chinese junk food, in which $58.73 \%$ were female subjects. They were associated with Anorectal problems $(\mathrm{OR}=1.43,95 \% \mathrm{CI}$ $0.83 ; 2.45)$ and Hypothyroidisms $(\mathrm{OR}=1.44,95 \% \mathrm{CI}$ $0.45 ; 4.55)$.

$79 \%$ subject was consuming Indian junk food. They were associated with Anorectal problems
$(\mathrm{OR}=1.30,95 \% \mathrm{CI} 0.65 ; 2.59)$, Indriye Daurbalya $(\mathrm{OR}=1.65,95 \% \mathrm{CI} \quad 0.94 ; 2.90)$, ADHD $(\mathrm{OR}=1.30$, $95 \% \mathrm{CI} 0.79 ; 2.14)$ and Anger $(\mathrm{OR}=1.38,95 \% \mathrm{CI} 0.86$; 2.21).

$32.50 \%$ were consuming other type of junk food (Pasta, Macaroni). They were associated with Skin Problem $(\mathrm{OR}=1.57,95 \% \mathrm{CI} 1.02 ; 2.40)$ and Anger $(\mathrm{OR}=1.45,95 \% \mathrm{CI} 0.97 ; 2.17)$.

$46.17 \%$ subjects were habitual to take sweetened beverages They were associated with GIT problems $(\mathrm{OR}=1.94$, 95\% CI $1.30 ; 2.91)$, Hypothyroidism $(\mathrm{OR}=1.85,95 \% \mathrm{CI} 0.58 ; 5.91)$, Locomotors problems $(\mathrm{OR}=1.31,95 \% \mathrm{CI} 0.90 ; 1.90)$ and $\mathrm{ADHD}(\mathrm{OR}=1.31,95 \% \mathrm{CI} 0.89 ; 1.94)$. In another study by Harrell et al, in New Delhi found that $30 \%$ school going children was consuming soft drink daily and $70 \%$ once in 2 days (15).

Table No 04: Viruddha Ahara consumption frequency and their health consequences

\section{\%of Youngsters eating viruddha Ahara. \\ Consumption of Type of Viruddha Ahara}

$87.50 \%(\mathrm{n}=525) \quad$ Vidhiviruddha Ahara. subjects were consuming $80 \%(n=480)$ subjects were consuming

$58 \% \quad(\mathrm{n}=348)$ subjects were consuming $47.83 \% \quad(\mathrm{n}=287)$ subjects were consuming $40.83 \% \quad(\mathrm{n}=245)$ subjects were consuming

$21.83 \% \quad(n=131)$
subjects were
consuming

$20 \% \quad(\mathrm{n}=120) \quad$ Paka viruddha Ahara. were consuming

Kramaviruddha Ahara

Samyogaviruddha Ahara Ahara.

\section{Health Consequences}

Parihar viruddha Ahara

Avastha viruddha

$19.33 \% \quad(\mathrm{n}=116)$

Karma viruddha Ahara subjects were consuming $19.33 \% \quad(\mathrm{n}=116) \quad$ Veerya viruddha Ahara were consuming
They all were associated with Skin problems $(\mathrm{OR}=1.40,95 \% \mathrm{CI}$ $0.80 ; 2.42)$, Indriye Daurbalya $(\mathrm{OR}=1.68,95 \% \mathrm{CI} 0.81 ; 3.49)$ and ADHD (OR $=2.82,95 \%$ CI $1.41 ; 5.63)$.

But in $80 \%, 58 \%(\mathrm{n}=348)$ were associated with Locomotors problems (OR $=1.49,95 \% \mathrm{CI} 0.91 ; 2.43)$, Indriye Daurbalya $(\mathrm{OR}=1.41,95 \% \mathrm{CI} 0.80 ; 2.49)$, $\mathrm{ADHD}(\mathrm{OR}=2.40,95 \% \mathrm{CI} 1.39$; $4.13)$ and Generalized Anxiety Disorder (OR=1.64, 95\%CI 1.01; 2.66).

They all were associated with Respiratory problems $(\mathrm{OR}=1.78$, $95 \%$ CI 1.07 ; 2.94).

They all were associated with Respiratory problems $(\mathrm{OR}=1.78$, $95 \%$ CI $1.10 ; 2.88)$.

They were associated with Respiratory problems $(\mathrm{OR}=1.64,95 \% \mathrm{CI}$ $1.01 ; 2.66)$, Anorectal problem (OR=1.50, 95\%CI 0.88; 2.59), Kidney stone $(\mathrm{OR}=1.56,95 \% \mathrm{CI} 0.58 ; 4.19)$, Locomotor problem $(\mathrm{OR}=1.4095 \% \mathrm{CI} 0.96 ; 2.05)$ and Indriye Daurbalya $(\mathrm{OR}=1.57$, $95 \%$ CI $1.03 ; 2.40)$.

They all were associated with Menstrual problems $(\mathrm{OR}=1.59$, $95 \%$ CI 0.97 ; 2.28), Nutritional problems ( $\mathrm{OR}=1.59,95 \% \mathrm{CI} 0.90$; 2.79), Hypothyroidism (OR=1.60, 95\% CI 0.46; 5.51) and Kidney Stone $(\mathrm{OR}=2.08,95 \% \mathrm{CI} 0.76 ; 5.69)$

They all were associated with Respiratory problems $(\mathrm{OR}=1.84$, 95\%CI 1.06; 3.19), Anorectal problem ( $\mathrm{OR}=1.42$, 95\%CI 0.75; 2.72), Hypothyroidism ( $\mathrm{OR}=2.90,95 \%$ CI $0.87 ; 9.68)$, Locomotor problem $(\mathrm{OR}=1.95$ 95\% CI 1.23; 3.10),ADHD $(\mathrm{OR}=1.45,95 \% \mathrm{CI}$ $0.90 ; 2.35)$ and Generalized Anxiety Disorders $(\mathrm{OR}=1.41,95 \% \mathrm{CI}$ $0.86 ; 2.30)$.

They all were associated with Respiratory problems $(\mathrm{OR}=1.91$, 95\%CI 1.11; 3.28), Menstrual Problem (OR=1.43, 95\%CI 0.91; $2.24)$ and Hypothyroidism $(\mathrm{OR}=2.78,95 \% \mathrm{CI} 0.85 ; 9.04)$.

They all were associated with Skin Problems $(\mathrm{OR}=1.32,95 \% \mathrm{CI}$ $0.81 ; 2.16)$, Hypothyroidism $(\mathrm{OR}=1.30,95 \% \mathrm{CI} 0.34 ; 4.94)$ and Mood Disorder (OR=1.39, 95\%CI 0.86; 2.24).

$34.50 \%(\mathrm{n}=207)$ subjects were doing Ajeereneashniyat. They were associated with GIT problems $(\mathrm{OR}=1.51$, $95 \%$ CI $0.97 ; 2.37)$, Skin problem $(\mathrm{OR}=1.36,95 \% \mathrm{CI} 0.88 ; 2.11)$, Respiratory problem (OR=1.98, 95\%CI $1.20 ; 3.26)$, Anorectal problem $(\mathrm{OR}=3.20$ 95\% CI 1.81; 5.66), Kidney stone ( $\mathrm{OR}=1.47,95 \% \mathrm{CI} 0.52 ; 4.11)$, Locomotors problems 
Ravi Verma et.al., Impact of Junk Food on Physical and Mental Health of the Youngsters - A Survey Study

$(\mathrm{OR}=1.39,95 \% \mathrm{CI} 0.93 ; 2.08)$, Indriye Daurbalya $(\mathrm{OR}=1.65,95 \% \mathrm{CI} 1.06 ; 2.58), \mathrm{ADHD}(\mathrm{OR}=1.73$ 95\%CI 1.15; 2.61) and Generalized Anxiety Disorder (OR=1.35, 95\%CI 0.88; 2.07).

$60.83 \%(\mathrm{n}=365)$ subjects were habitual to consuming packed food. They were associated with Skin problems $(\mathrm{OR}=1.52,95 \% \mathrm{CI} 1.04 ; 2.26)$, Hypothyroidism $(\mathrm{OR}=2.32,95 \% \mathrm{CI} 0.67 ; 8.78)$ and $\mathrm{ADHD}(\mathrm{OR}=1.31,95 \% \mathrm{CI} 0.87$; $1.96)$.

$8.17 \%(\mathrm{n}=49)$ subjects were consuming curd with non-vegetarian diet. They were associated with GIT problems $(\mathrm{OR}=1.92,95 \% \mathrm{CI} 0.80 ; 4.58)$, Respiratory problem $(\mathrm{OR}=2.73,95 \% \mathrm{CI} 1.31 ; 5.71)$, Menstrual problem $(\mathrm{OR}=2.17,95 \% \mathrm{CI} 1.16 ; 4.06)$, Hypothyroidism $(\mathrm{OR}=1.9495 \% \mathrm{CI} 0.38 ; 9.80)$ and Mood Disorders $(\mathrm{OR}=2.44,95 \% \mathrm{CI}$ $1.20 ; 4.97)$.

Large portion size, high amount of refined carbohydrates and added sugar, and high glycemic load are the characteristics of fast food. Consumption of added sugars has been associated with increased risk of obesitylas well as increased risk factors for cardiovascular disease (16), including dyslipidemia, elevated blood pressure, diabetes (17), non-alcoholic fatty liver disease (18) and even cognitive decline (19) and cancer (20). Another research indicating that high consumption of ultra-processed foods associated with higher prevalence of Metabolic Syndrome in adolescents and risk of insulin resistance (21). The participants in the present study also showed multiple systemic problems which can cause various NCD's in future.

Generally, consumption of viruddha ahara lead to vitiation in Dosha \& Dhatu (22) and Agni (23) which is root cause of development of every disease. Because vitiation in Jatharagni leads to vitiation of Dhatvagni and Bhutagni. This imbalance in Agni can produce Ama in the body which can disturb the immune system \& vitiate all the Doshas and the srotas then by obstructing these srotas can cause various dangerous diseases.

\section{Observed Physical health consequences in all participants (represented in Table no 05 and Graph No 01)}

In the present study, out of total 600 subjects, $(n=485) 80.83 \%$ were suffering from nutritional problems (Hair fall, Hair graying). It may be because junk food lack in micronutrients. $73.50 \%(n=441)$ subjects were suffering from various kinds of skin problem (Acne, Eczema, Urticaria, white spots and skin rashes). In another study Talekar M. also observed that $23.55 \%$ subjects were suffering from skin disease those were consuming Viruddha Ahara (24).

In present survey study $31.22 \%(\mathrm{n}=197)$ were suffering from PMS, PCOD. In a cross-sectional survey Raval $\mathrm{CM}$ et al. found in 489 college girls $18.4 \%$ were suffering from moderate to severe PMS (25). In the present study $73.33 \%(\mathrm{n}=440)$ subjects were suffering from GIT problems (Abdominal pain, abdominal distension, constipation, acidity and IBS), 30.83\% $(\mathrm{n}=185)$ were having Locomotors problems (Stiffness in neck, joint pain), 20.83\% $(\mathrm{n}=125)$ were having Indriyedaurbalya (using spectacle), $14.50 \%(\mathrm{n}=87)$ were having Respiratory problems (Asthma), $11.33 \%$ $(n=68)$ were having Anorectal problem (Piles, Fissure, Fistula), 3.00\% $(n=18)$ were having Kidney stone and $2.17 \%$ $(\mathrm{n}=13)$ were having Hypothyroidism.

Table No 5: Observation of Physical Health Problems in Survey Subjects

\begin{tabular}{|c|c|c|c|c|c|}
\hline Physical Health Problem & $\begin{array}{c}\text { 12-18 Years } \\
(n=324)\end{array}$ & $\begin{array}{c}19-25 \text { Years } \\
(n=276)\end{array}$ & $\begin{array}{c}\text { Total } \\
(n=600)\end{array}$ & $\begin{array}{c}\text { Male } \\
(n=222)\end{array}$ & $\begin{array}{l}\text { Female } \\
(n=378)\end{array}$ \\
\hline GIT & $\begin{array}{c}211 \\
(47.95 \%)\end{array}$ & $\begin{array}{c}229 \\
(52.05 \%)\end{array}$ & $\begin{array}{c}440 \\
(73.33 \%)\end{array}$ & $\begin{array}{c}142 \\
(32.27 \%)\end{array}$ & $\begin{array}{c}298 \\
(67.73 \%)\end{array}$ \\
\hline SKIN & $\begin{array}{c}243 \\
(55.10 \%)\end{array}$ & $\begin{array}{c}198 \\
(44.90 \%)\end{array}$ & $\begin{array}{c}441 \\
(73.50 \%)\end{array}$ & $\begin{array}{c}176 \\
(39.91 \%)\end{array}$ & $\begin{array}{c}265 \\
(60.09 \%)\end{array}$ \\
\hline RESPIRATORY & $\begin{array}{c}34 \\
(39.08 \%)\end{array}$ & $\begin{array}{c}53 \\
(60.92 \%)\end{array}$ & $\begin{array}{c}87 \\
(14.50 \%)\end{array}$ & $\begin{array}{c}30 \\
(34.48 \%)\end{array}$ & $\begin{array}{c}57 \\
(65.52 \%)\end{array}$ \\
\hline ANORECTAL & $\begin{array}{c}22 \\
(32.35 \%)\end{array}$ & $\begin{array}{c}46 \\
(67.65 \%)\end{array}$ & $\begin{array}{c}68 \\
(11.33 \%)\end{array}$ & $\begin{array}{c}21 \\
(20.88 \%)\end{array}$ & $\begin{array}{c}47 \\
(69.12 \%)\end{array}$ \\
\hline MENSTRUAL & $\begin{array}{c}49 \\
(41.53 \%)\end{array}$ & $\begin{array}{c}69 \\
(58.47 \%)\end{array}$ & $\begin{array}{c}118 \\
(31.22 \%)\end{array}$ & $\begin{array}{c}0 \\
(0 \%)\end{array}$ & $\begin{array}{c}118 \\
(31.22 \%)\end{array}$ \\
\hline NUTRITIONAL & $\begin{array}{c}243 \\
(50.10 \%)\end{array}$ & $\begin{array}{c}242 \\
(49.90 \%)\end{array}$ & $\begin{array}{c}485 \\
(80.83 \%)\end{array}$ & $\begin{array}{c}163 \\
(33.61 \%)\end{array}$ & $\begin{array}{c}322 \\
(66.39 \%)\end{array}$ \\
\hline HYPOTHYROID & $\begin{array}{c}5 \\
(38.46 \%)\end{array}$ & $\begin{array}{c}8 \\
(61.54 \%)\end{array}$ & $\begin{array}{c}13 \\
(2.17 \%)\end{array}$ & $\begin{array}{c}3 \\
(23.08 \%)\end{array}$ & $\begin{array}{c}10 \\
(76.92 \%)\end{array}$ \\
\hline KIDNEY STONE & $\begin{array}{c}7 \\
(38.89 \%)\end{array}$ & $\begin{array}{c}11 \\
(61.11 \%)\end{array}$ & $\begin{array}{c}18 \\
(3.00 \%)\end{array}$ & $\begin{array}{c}4 \\
(22.22 \%)\end{array}$ & $\begin{array}{c}14 \\
(77.78 \%)\end{array}$ \\
\hline LOCOMOTOR & $\begin{array}{c}83 \\
(44.86 \%)\end{array}$ & $\begin{array}{c}102 \\
(55.14 \%)\end{array}$ & $\begin{array}{c}185 \\
(30.83 \%)\end{array}$ & $\begin{array}{c}66 \\
(35.68 \%)\end{array}$ & $\begin{array}{c}119 \\
(64.32 \%)\end{array}$ \\
\hline INDRIYE DAURBALYA & $\begin{array}{c}49 \\
(39.20 \%)\end{array}$ & $\begin{array}{c}76 \\
(60.80 \%)\end{array}$ & $\begin{array}{c}125 \\
(20.83 \%)\end{array}$ & $\begin{array}{c}38 \\
(30.40 \%)\end{array}$ & $\begin{array}{c}87 \\
(69.60 \%)\end{array}$ \\
\hline
\end{tabular}




\section{Graph1: Impact of Viruddha Ahara (Junk Food) on Physical Health in 600 Youngsters of Bhopal City}

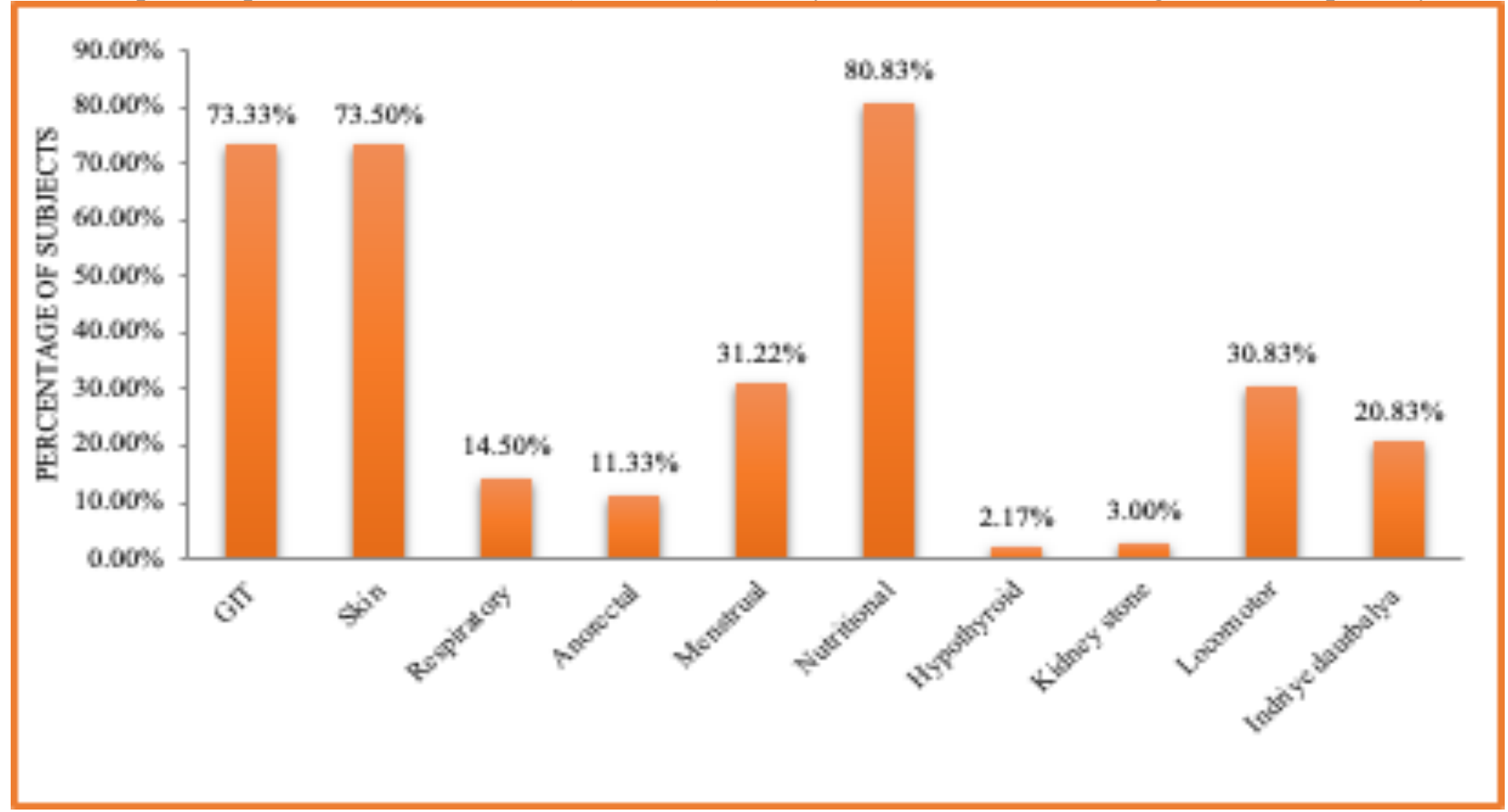

\section{Observed Mental health consequences in all participants (represented in table no 06 and Graph No 02)}

Junk food has a negative effect on mental health. High-fat, high-sugar diets can affect proteins that are important in brain development, such as the signaling molecule brain-derived neurotrophic factor (26). In the present survey $23.33 \%$ subjects $(n=140)$ were found suffering from mild to moderate depression, in which maximum $67.86 \%$ $(\mathrm{n}=95)$ subjects were belonging to age between 19-25 years. A cohort study conducted by Sánchez A. in 2012 found higher risk of depression was associated with consumption of fast food (hamburgers, sausages, pizza) (hazard ratio $(\mathrm{HR})=1 \cdot 36 ; 95 \% \mathrm{CI} 1 \cdot 02,1 \cdot 81 ; \mathrm{P}$ trend $=0 \cdot 003)$.

In the present survey $30.17 \%(\mathrm{n}=181, \mathrm{~F}-67.96 \%, \mathrm{M}-32.04 \%)$ subjects were having ADHD. The percent was higher $59.12 \%$ in age between $12-18$ years than $40.88 \%$ in age between 19-25 years. McCann, Donna et al. in the study revealed artificial colors or a sodium benzoate preservative (or both) in the diet result in increased hyperactivity in 3-year-old and 8/9-year-old children (27).

In the present survey $58.67 \%(\mathrm{n}=352)$ subjects were having generalized anxiety disorder, $38.50 \%(\mathrm{n}=231)$ were suffering from mood disorders and $40.83 \%(\mathrm{n}=245)$ were experiencing frequent anger. Same observation found by Bakhtiyari $\mathrm{M}$ et al., in a cross-sectional study on students of medical sciences universities in Tehran observed seven folds higher anxiety found in students who frequently consume fast-food cuisine than those students who rarely use fast food $(\mathrm{OR}=7.0,95 \% \mathrm{CI}, 2.35-9.74, \mathrm{P}<0.001)$ it was also determined that rate of anxiety level might increase by increase in consumption of fast- food cuisine (28).

Table No 6: Observed Mental Health Problems in Survey subjects

\begin{tabular}{|c|c|c|c|c|c|}
\hline Mental Health Problems & $\begin{array}{l}\text { 12-18 Years } \\
(\mathrm{n}=324)\end{array}$ & $\begin{array}{l}\text { 19-25 Years } \\
\quad(\mathrm{n}=276)\end{array}$ & $\begin{array}{c}\text { Total } \\
(\mathrm{n}=600)\end{array}$ & $\begin{array}{c}\text { Male } \\
(\mathrm{n}=222)\end{array}$ & $\begin{array}{l}\text { Female } \\
(\mathrm{n}=378)\end{array}$ \\
\hline DEPRESSION & $\begin{array}{c}49 \\
(35.00 \%)\end{array}$ & $\begin{array}{c}91 \\
(65.00 \%)\end{array}$ & $\begin{array}{c}140 \\
(23.33 \%)\end{array}$ & $\begin{array}{c}45 \\
(32.14 \%)\end{array}$ & $\begin{array}{c}95 \\
(67.86 \%)\end{array}$ \\
\hline ADHD & $\begin{array}{c}107 \\
(59.12 \%)\end{array}$ & $\begin{array}{c}74 \\
(40.88 \%)\end{array}$ & $\begin{array}{c}181 \\
(30.17 \%)\end{array}$ & $\begin{array}{c}58 \\
(32.04 \%)\end{array}$ & $\begin{array}{c}123 \\
(67.96 \%)\end{array}$ \\
\hline $\begin{array}{l}\text { GENERALIZED ANXIETY } \\
\text { DISORDER }\end{array}$ & $\begin{array}{c}201 \\
(57.10 \%)\end{array}$ & $\begin{array}{c}151 \\
(42.90 \%)\end{array}$ & $\begin{array}{c}352 \\
(58.67 \%)\end{array}$ & $\begin{array}{c}134 \\
(38.07 \%)\end{array}$ & $\begin{array}{c}218 \\
(61.93 \%)\end{array}$ \\
\hline MOOD DISORDER & $\begin{array}{c}142 \\
(61.47 \%)\end{array}$ & $\begin{array}{c}89 \\
(38.53 \%)\end{array}$ & $\begin{array}{c}231 \\
(38.50 \%)\end{array}$ & $\begin{array}{c}89 \\
(38.53 \%)\end{array}$ & $\begin{array}{c}142 \\
(61.47 \%)\end{array}$ \\
\hline ANGER & $\begin{array}{c}127 \\
(51.84 \%)\end{array}$ & $\begin{array}{c}118 \\
(48.16 \%)\end{array}$ & $\begin{array}{c}245 \\
(40.83 \%)\end{array}$ & $\begin{array}{c}89 \\
(36.33 \%)\end{array}$ & $\begin{array}{c}156 \\
(63.67 \%)\end{array}$ \\
\hline
\end{tabular}




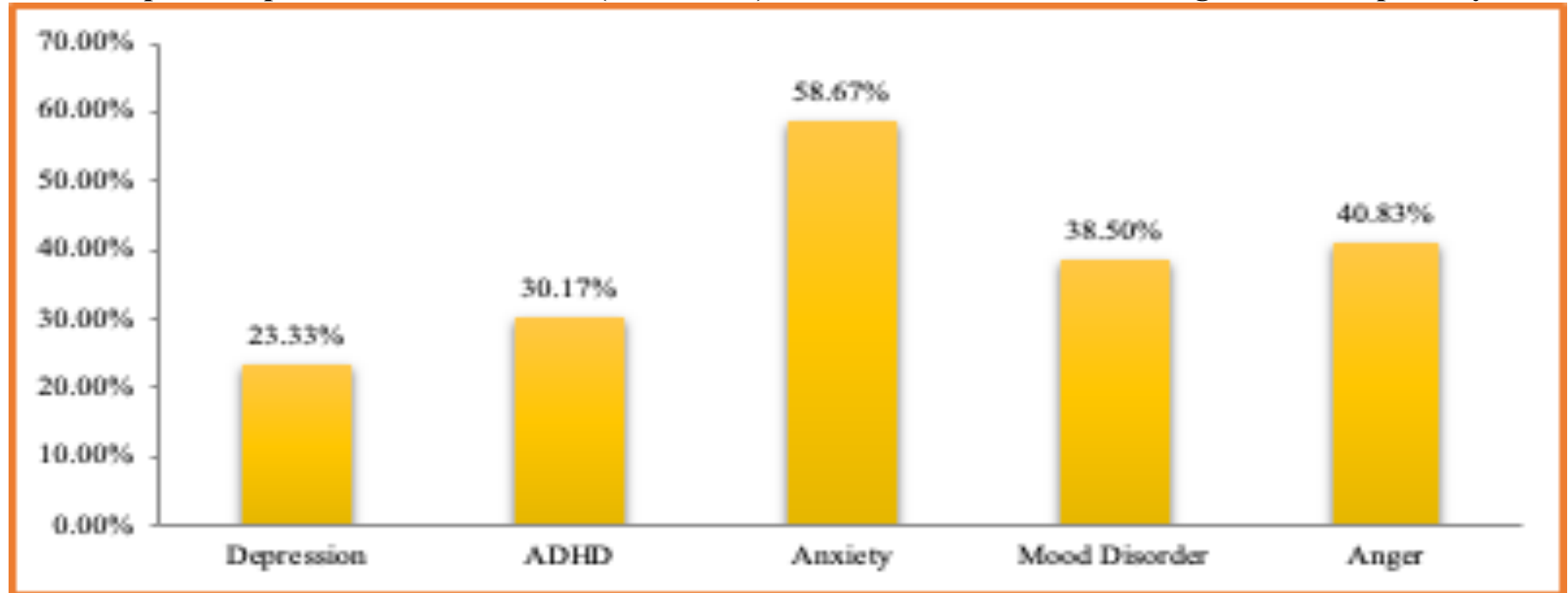

\section{Conclusion}

Result of Survey Study indicating that all subjects were consuming various types of junk food and Viruddha Ahara (incompatible diet) and various physical and mental health consequences were found significantly linked with high consumption of Viruddh Ahara (Junk food). It could be concluded that consumption of Viruddha Ahara (Junk food) has significant adverse impact on physical and mental health of youngsters.

\section{Limitation}

This study was carried out on small sample size because of the limitations of the resources.

\section{Further Recommendations}

Future observational research could be carried out exclusively with single Viruudha Ahara or a single junk food effect on physical and mental health.

\section{References}

1. Shastri K., Chaturvedi G. Charak Samhita of Agnivesha Sutra Sthana. 18 $18^{\text {th }}$ edition. Varanasi; Chaukhambha Bharti Academy; 1992; 523p.

2. Must A., Spadano J., Coakley E.H, et.al. The disease burden associated with overweight and obesity. JAMA[Internet]. 1999 Oct [cited 2020 Mar 20]; 282(16):1523-1529. Available from: https:// www.ncbi.nlm.nih.gov > pubmed.

3. Braithwaite I., Stewart A.W., Hancox R.J, et.al. Fast-food consumption and body mass index in children and adolescents: an international crosssectional study. BMJ Open[Internet]. 2014[cited 2020 Mar 20]; 4: e005813. Available from: https:// www.researchgate.net/publication/269413486 Fastfood_consumption_and_body_mass_index_in_child ren_and_adolescents_an_international_crosssectional_study

4. Kawatra A., Trygg N., Parhar G., Mohta A. Waist circumference and Waist height ratio percentiles for assessing childhood obesity: Cross-Sectional Survey in rural Indian child population. Indian
Journal of Basic and Applied Medical Research[Internet]. December 2013[cited 2020 Mar 20]; 3(1): 246-256. Available from: ijbamr.com > pdf > PDF DECEMBER 13 246-256.pdf.pdf

5. Cole T.J., Bellizzi M.C., Flegal K.M., Dietz W.H. Establishing a standard definition of child over weight and obesity worldwide: international survey. The British Medical Journal[Internet]. 2000 [cited 2020 Mar 20]; 320:1-6. Available from: https:// www.ncbi.nlm.nih.gov > pubmed

6. Ranasinghe C.D, Ranasinghe P., Jayawardena R., Mishra A. Physical activity patterns among SouthAsian adults: a systematic review. International Journal of Behavioral Nutrition and Physical Activity[Internet]. 2013[cited 2020 Mar 20]; 10:116 Available from: https://www.ncbi.nlm.nih.gov , pubmed

7. Siddiqui N. et al. Prevalence and trends of obesity in Indian school children of different socioeconomic class. Indian Journal of Basic \& Applied Medical Research[Internet]. December 2012[cited 2020 Mar 20]; 2(5): 393-398. Available from: ijbamr.com $>$ pdf

8. Faris A. L, Tamimi-Al, Jobair M.O, et al. Trends of fast food consumption among adolescent and young adult Saudi girls living in Riyadh. Food \& Nutrition Research[Internet]. 2015[cited 2020 Mar 20]; 59: 26488 . Available from: https:// foodandnutritionresearch.net , index.php > fnr , article > view

9. Gebremedhin S., Enquselassie F., Umeta M. Prevalence and correlates of maternal anemia in rural Sidama, Southern Ethiopia. Afr. J Reprod Health[Internet]. 2014 Mar[cited 2020 Mar 20]; 18(1); 44-53. Available from: www.bioline.org.br > pdf

10. Rouhani M.H., Mirseifinezhad M., Omrani N., Esmaillzadeh A., Azadbakht L. Fast Food Consumption, Quality of Diet, and Obesity among Is fahanian Adolescent Girls. J Obes[Internet]. 2012[cited 2020 Mar 20]; 2012: 597924 . Available from: https:// www.ncbi.nlm.nih.gov/pubmed/22619703 
11. Faris A.L., Tamimi-Al, Jobair M.O., et al. Trends of fast food consumption among adolescent and young adult Saudi girls living in Riyadh. Food \& Nutrition Research[Internet]. 2015[cited 2020 Mar 20]; 59: 26488 . Available from: https:// foodandnutritionresearch.net , index.php > fnr , article > view

12. Li M. et al. Dietary habits and overweight/obesity in adolescents in Xi'an City, China. Asia Pac J Clin Nutr [Internet]. 2010[cited 2020 Mar 20]; 19(1):76-82. Available from: https:// www.researchgate.net/publication/ 41721798_Dietary_habits_and_overweightobesity in_adolescents_in_Xi\%27an_City_China

13. Savige G., MacFarlane A., Crowford D., et al. Snacking behaviors of adolescents and their association with skipping meals. International Journal of Behavioral Nutrition and Physical Activity[Internet]. 2007[cited 2020 Mar 20]; 4:36. Available from: https://www.researchgate.net , publication > 5973172_Snacking_behaviors_...

14. Thompson O.M., Ballew C., Resnicow K., et al. Food purchased away from home as a predictor of change in BMI z-score among girls. Int J Obes Relat Metab Disord[Internet]. 2004 [cited 2020 Mar 20]; 28: 282-9. Available from: https:// www.ncbi.nlm.nih.gov > pubmed

15. Harrell M., Medina J., Greene Cramer B., Sharma S.V., Arora M., Nazar G. Understanding eating behaviors of New Dehli's youth. J Appl Res Child[Internet]. 2016[cited 2020 Mar 20]; 6:8. Available from: files.eric.ed.gov > fulltext

16. Bray G.A. Fructose and risk of cardiometabolic disease. Curr Atheroscler Rep[Internet]. 2012[cited 2020 Mar 20]; 14(6):570-578. Available from: https://www.ncbi.nlm.nih.gov > pubmed

17. Basu S., Yoffe P., Hills N., Lustig R.H. The relationship of sugar to population-level diabetes prevalence: An econometric analysis of repeated c ross-sectional d a ta. P LoS ONE[Internet]. 2013[cited 2020 Mar 20]; 8(2): e57873. Available from: https://journals.plos.org > plosone > article > journal.pone. 0057873

18. Clark J.M. The epidemiology of nonalcoholic fatty liver disease in adults. J. Clin. Gastroenterol[Internet]. 2006[cited 2020 Mar 20]; 40: S 5-S10. Available from: https:// www.ncbi.nlm.nih.gov > pubmed

19. Stephan B.C., Wells J.C., Brayne C., Albanese E., Siervo M. Increased fructose intake as a risk factor for dementia. J. Gerontol. A. Biol. Sci. Med. Sci[Internet]. 2010[cited 2020 Mar 20]; 65:809814 . Available from: https:// pubmed.ncbi.nlm.nih.gov/20504892/

20. Bartrina J.A., Rodrigo C.P. Association between sucrose intake and cancer: A review of the evidence. Nutr. Hosp[Internet]. 2013[cited 2020 Mar 20]; 4:95-105. Available from: https:// pubmed.ncbi.nlm.nih.gov/23834098/

21. Hsieh S., Klassen A.C., Curriero F.C., Caulfield L.E., Cheskin L.J., Davis J.N., et al. Fast-food restaurants, park access, and insulin resistance among Hispanic youth. American journal of preventive medicine[Internet]. 2014[cited 2020 Mar 20]; 46(4):378-87. Available from: https:// www.ncbi.nlm.nih.gov > pubmed

22. Shastri A. Susruta Samhita of Maharshi Susruta Sutrasthana. 12 $2^{\text {th }}$ edition. Varanasi; Chaukhambha Sanskrit Sansthan, 2001; 85p.

23. Shukla A.V.,Tripathi R.V. Charaka Samhita of Agnivesha Chikitsa Sthana. $1^{\text {st }}$ edition. Varanasi; Chaukhamba Sanskrit Sansthan, 2007; 367p.

24. Talekar M. et al. Prevalence of Viruddha ahara in Patients Attending Arogyashala of N.I.A and Its Effects on Health. International Journal of Advanced Ayurveda, Yoga, Unani, Siddha and Homeopathy[Internet]. 2015[cited 2020 Mar 20]; 4(1): 297-303. Available from:

25. Raval C.M., Panchal B.N., Tiwari D.S., Vala A.U., Bhatt R.B. Prevalence of premenstrual syndrome and premenstrual dysphoric disorder among college students of Bhavnagar, Gujarat. Indian J Psychiatry[Internet]. 2016 Apr-Jun [cited 2020 Mar 20]; 58(2): 164-170. Available from: www.indianjpsychiatry.org, article , issn=0019-5545; year=2016; volume

26. Molteni R., Barnard R., Ying Z., Roberts C., Gomez-Pinilla F. A high-fat, refined sugar diet reduces hippocampal brain-derived neurotrophic factor, neuronal plasticity, and learning. Neuroscience[Internet]. 2002[cited 2020 Mar 20];112(4):803-814. Available from:

27. McCann D., Barrett A., Cooper A., Crumpler D., Dalen L., Grimshaw K. et al. Food additives and hyperactive behaviour in 3-year-old and 8/9-yearold children in the community: a randomised, doubleblinded, placebo controlled trial. Lancet[Internet]. 2007 Nov [cited 2020 Mar 20]; 370(9598):1560-7. Available from: https:// www.ncbi.nlm.nih.gov > pubmed

28. Bakhtiyari M., Ehrampoush E., Enayati N., Rastmanesh R. Correlation between fast food consumption and levels of anxiety in students of medical science universities in Tehran. Journal of Fundamentals of Mental Health[Internet]. 2011[cited 2020 Mar 20]; 13(3): 212-21. Available from: https://www.researchgate.net/publication/ 264202742_Correlation_between_fast_food_consu mption_and_levels_of_anxiety_in_students_of_me dical_science_universities_in_Tehran. 